Ж. В. Колоїз

докт. філол. наук, доцент

\title{
ОСНОВНІ ПІДХОДИ ДО ВИЗНАЧЕННЯ ЛІНГВІСТИЧНОГО СТАТУСУ НЕОЛОГІЗМУ
}

У статті розглянуто основні підходи до визначення лінгвістичного статусу неологізму та його співвідношення з поняттям «оказіоналізм»; критерій новизни визначено як неадаптований, унікальний, винятковий якісний стан, який характеризується неповторністю та неподібністю до вже адаптованих.

У багатьох лінгвістичних дослідженнях, де порушують питання мовного розвитку, як у вітчизняному, так і в зарубіжному мовознавстві відзначено, що лексика піддається змінам більшою мірою, ніж інші структурні мовні рівні, і ці зміни залежать насамперед від позамовного навколишнього світу. Внутрішні й зовнішні стимули лексичних змін сприяють появі таких мовних явищ, які отримали кваліфікацію неологізмів, що $є$ основними показниками темпів розвитку лексики. Подібний підхід, цілком закономірно, визначає лексичну природу неологізму і його статус периферійної оди- 
ниці лексичної системи. 3 позицій сучасних лінгвістичних досягнень витлумачення неологізму лише як одиниці лексичної системи ускладнює проблему диференціації та систематизації неологічного матеріалу.

Традиційне ототожнення неологізму 3 новим словом явно свідчить про звуження визначення цього терміна і спонукає до слушного запитання: Що все ж таки слід вкладати в поняття «неологізм» і на основі чого здійснювати систематизацію неологічного матеріалу?

У перекладі з грецької неологізм у буквальному витлумаченні означає «нове слово» і саме через слово (лише через слово) пояснюється в багатьох теоретичних розвідках. До розряду неологізмів зараховують лексеми, що, репрезентуючи нову, нетрадиційну форму вираження, набувають, відповідно, й нового, нетрадиційного змісту. Подібні визначення з'ясовують сутність, так би мовити, лексичних неологізмів, «у яких на тому чи іншому етапі розвитку мови новими $\epsilon$ і зміст, і звукова оболонка слова» $[16,243]$. Термінологічне сполучення «лексичний неологізм» логічно передбачає, що, крім названого типу, мали б мати місце й інші, бо використання для означення одного і того ж мовного явища подвійної термінології позбавлене будь-якого смислу. А тому згодом лексичним неологізмам починають протиставляти семантичні, «у яких стара звукова оболонка слова наповнюється новим змістом» $[16,243]$.

Починаючи 3 другої половини XIX століття, визначення неологізму розширюється, його структурна характеристика передбачає не тільки слово, але й одиниці-конструкції. Так, у «Словнику лінгвістичних термінів» $€$. Кротевича, Н. Родзевич неологізм витлумачено як «слово, словосполучення або вираз, що з'являється у мові в зв'язку з виникненням нових понять, у зв'язку з ростом культури, техніки, з розвитком або зміною суспільних відносин» $[10,102]$; однойменний словник Д. Ганича, I. Олійника кваліфікує його як «слово або мовний зворот, створені для позначення нового предмета чи вираження нового поняття» $[5,151]$. Аналогічна структурна характеристика неологізму представлена в енциклопедії «Українська мова» («слово, а також його окреме значення, вислів, які з'явилися в мові на даному етапі iї розвитку і новизна яких усвідомлюється мовцями (загальномовні неологізми) або були вжиті тільки в якомусь акті мовлення, тексті чи мові певного автора (стилістичні, або індивідуально-авторські неологізми)» $[17,377])$.

Подібні тлумачення не викликають принципового заперечення. Однак незрозуміло, чому словосполучення, вирази, мовні звороти, які в наведених визначеннях підведено під поняття «неологізм», насправді ж обділені увагою дослідників. Ілюстративний матеріал, поданий для підтвердження теорії, за межі лексеми, нового слова (рідше нового значення), як правило, не виходить. Без відповіді залишається й запитання: Чому і які нові словосполучення, вирази, мовні звороти зараховують до одиниць лексичного рівня, тобто до лексичних неологізмів? Водночас не можна не констатувати 
невизначеності, розпливчастості ознак, на яких грунтується диференціація неологізмів, на чому неодноразово наголошували дослідники. Критерій «новизни», що виокремлюють як основну ознаку неологізму, доволі нечіткий, позбавлений конкретики, всеосяжний. А отже, нібито цілком зрозумілими теоретичними положеннями на кшталт «нове слово є неологізмом тільки до того часу, допоки воно має на собі відбиток свіжості, допоки мовець усвідомлює його предметно-логічну новизну або стилістичну своєрідність $\langle\ldots>$, допоки його повністю не засвоїть мова й воно не увійде до активного запасу лексики, допоки його сприймають як слово, яке має відтінок свіжості та незвичності» [19, 156-157] досить важко скористатися на практиці і передусім тому, що «відчуття новизни - це суто індивідуальна властивість кожної людини», воно визначається ступенем освіченості адресата, його смаками, мовним чуттям тощо $[12,245]$. Проблему ускладнює також і те, що мовознавці не одностайні у своїх поглядах не тільки щодо неологізму, але й щодо нового слова зокрема. «Виникає запитання про те, що ж таке «нові» слова в мові: ті, що ще не з'явилися? - тоді чи «слова» це; ті, що вже «з'явилися», але не увійшли до активного вжитку? - тоді це ще не слова мови; ті, що вже увійшли в мову? - тоді чим ці «нові» слова в словотвірному плані відрізняються від «старих?» [15, 17], адже «у самому неологізмі неначебто $є$ і нове, і старе. Новими $є$ і поняття, і слово, старими - усі наявні ресурси мови, на основі яких утворено це нове слово» $[3,88]$.

Спроба дати відповідь на ці та ряд інших запитань сприяла появі низки термінів, що мали на меті диференціювати нові явища. Поряд із традиційними термінами «нове слово», «неологізм» починають функціонувати «потенційне слово», «оказіональне слово», «оказіоналізм», «індивідуально-авторський неологізм», «авторський неологізм», «стилістичний неологізм», «індивідуально-стилістичний неологізм», «одноразовий неологізм», «літературний неологізм», «неологізм поета», «поетичний неологізм», «слово-метеор» тощо. Деякі з цих термінів, як і самі слова-«метеори», не витримали випробовування часом і залишилися тільки в працях, де обгрунтовувалася саме їх доцільність.

Найбільша продуктивність щодо вживання характерна для терміна «неологізм», мабуть, тому, що дефініція «неологізмами $є$ нові слова» передбачає всі типи нових слів, зокрема й ті, які не стали загальномовним надбанням. Атрибути на кшталт «індивідуально-авторський», «авторський», «поетичний», «стилістичний», «художній» і т. ін., що супроводжували неологізм, виокремлювали конкретний різновид з-поміж сукупності неологічного матеріалу. 3 усієї розмаїтості неологічних термінів на означення «мовленнєвих неологізмів» найприйнятнішим виявилося утворення 3 компонентом «індивідуально-авторський», паралельно 3 яким у науковий обіг уводять й «оказіоналізм», або «оказіональне слово». Поняття «індивідуально-авторські неологізми», «оказіоналізми», «оказіональні слова», як правило, використовують для означення тотожних мовленнєвих фактів, 
подекуди аналізують у дихотомії «оказіональне-потенційне». Однак щодо їх співвідношення, то зауважимо, що мовознавці висловлюють різні, часто суперечливі погляди.

Диференціація потенційних та оказіональних різновидів індивідуально-авторських утворень не позбавлена штучності, а деінде й алогічності. Так, в одному 3 посібників 3 російського словотвору конкретне слово ympemь зараховують до розряду потенційних, бо, як стверджують автори, воно утворене за аналогією до вечереть $[2,13]$, натомість лексеми привенериться, примарситься, приюпитериться необгрунтовано (аналогія 3 узуальним приземлиться цілком очевидна) означають як оказіональні [2, 28]. Більше того, аналогічно утворене слово прилуниться виходить за межі представленого ряду, йому надано статус потенційного. Аналізуючи українську лексику, структурним компонентом якої виступає компонент -ман, О. Муромцева серед аналогічно утворених слів хлопоман, украӥноман, ляхоман, козакоман виокремлює як оказіоналізм тільки галіціоман $[13,58]$.

Беручи до уваги твердження на кшталт «оказіональні слова - антиподи слів потенційних, оскільки останні спродуковані за законами словотворення» $[7,353]$, серед наведених прикладів узагалі не повинно би бути оказіоналізмів: і привенериться, і примарситься, і приюпитериться відповідають законам та правилам дієслівного словотворення. А тому висловлена думка спонукає до дискусії, адже будь-який неологізм, що з'являється в лексиці, не може бути новотвором, сконструйованим поза правилами та законами словотворення, семантичної системи і граматичної будови. «Слово, створене без дотримання названих вище особливостей, буде мертвонародженим, непотрібним і безглуздим набором звуків» $[19,161]$. Розглядаючи потенційні та оказіональні слова як антиподи, О. Земська свідома того, що «нерідко буває важко встановити, являє собою це чи те новоутворення слово потенційне, яке реалізує словотвірні можливості типу, чи слово оказіональне», наприклад, вьетнамизация, фельдиеризация, космизация, роботизація [6, 27]. I такі випадки, на жаль, не є поодинокими. Попри сказане, дослідниця наполегливо відшукує ту точку, де «антиподи (слова потенційні і слова оказіональні) сходяться», ту пограничну межу, де оказіональне переходить у потенційне. «Потенційні й оказіональні слова репрезентують два полюси словотворення <..>. Однак і ті, й інші демонструють можливості, закладені в системі мови, тільки в першому випадку - це можливості, які вже проторували собі шлях, а в другому - це можливості глибинні, що зрідка, дуже важко прокладають собі шлях на поверхню. Цілком імовірно, що якась частина останніх за їх особливої активності, сприятливих внутрішньомовних умов і допомоги суспільних факторів отримає путівку в буття» $[6,27]$. Якщо можливість уже «проторувала собі шлях», вона відбулася, а тому не може бути «потенційним словом» у прямому його витлумаченні: потенційне слово - це лише місце в системі мови. Матеріально 
оформлене, реально представлене в мовленні слово не $є$ потенційним, бо очевидно, що реалізоване водночас не може бути потенційним.

У сучасній неології спостерігаємо також намагання протиставити оказіоналізм індивідуально-авторському неологізму (попри те, що і перші, i другі розглядають як одиниці мовлення) на тій підставі, що оказіональні, так би мовити, не-авторські «новоутворення продукуються в розмовному мовленні і їх творцем $є$ народ», а індивідуально-авторські, або авторські, створюються з певною стилістичною метою $[14,12]$. Наполягаючи на розрізненні оказіоналізмів і поетичних неологізмів, О. Александрова вмотивовує його необхідність таким чином: «Оказіоналізми в мовленнєвому акті $\epsilon$ засобом виконання металінгвістичної функції, засобом переведення смислу, інформації з однієї функціональної підсистеми мови в іншу. Новоутворення в цьому випадку не містить інформації про щось нове, виокремлене внаслідок об'єктивного (тобто колективного) пізнання навколишнього світу, воно передає інформацію про відоме, але іншим способом. У результаті такого перейменування відбувається прирощення інформації, адже «переведення однієї групи знаків в іншу неминуче супроводжується зміною інтерпретації <...>. Поетичний неологізм $\epsilon$ засобом реалізації поетичної функції. Новоутворення в цьому випадку містить інформацію про нове, виокремлене внаслідок суб'єктивного (індивідуального) пізнання навколишнього світу» $[1,16]$.

Щодо першого обгрунтування, то ми не бачимо принципової різниці між оказіоналізмами авторськими (письменницькими) й оказіоналізмами, які не претендують на авторство (установити його неможливо) - дитячими та розмовними, оскільки, по-перше, саме в цих трьох сферах і створюються оказіоналізми; по-друге, кожен витвір має свого творця, а тому кожне новоутворення належить окремому індивідууму. Навіть ті мовознавці, які у своїй теорії інноваційних процесів зіставляють узуальні, потенційні й оказіональні явища, свідомі того, що «стадію оказіональності проходять усі новоутворення, незалежно від того, яким шляхом вони були спродуковані» $[2,13]$.

Наскрізь суперечливим є намагання диференціювати поетичні неологізми/оказіоналізми за параметрами поетична/металінгвістична функції, нова/ненова інформація як результат суб'єктивного/об' єктивного пізнання навколишнього світу. Безумовно, індивідуально-авторські новотвори різняться щодо причин, які сприяли їх появі, однак останні завжди відображають і суб'єктивний фактор: і грифенята, і вербенята, які дослідниця кваліфікує, відповідно, як оказіоналізм та поетичний неологізм, є результатами суб'єктивного пізнання навколишнього світу; і в першому, і в другому випадку має місце творче перетворення дійсності, образність і метафоричність. Їх диференціація відбувається з тієї простої причини, що оказіоналізм грифенята можна «роздягнути», «звільнити від метафори», замінити необразним описовим зворотом (вихованиі «Грифа») без будь-якої шко- 
ди для змісту, а поетичний неологізм вербенята піддати такій операції неможливо [1, 17-20].

Подібні наукові пошуки внесли новий поворот і в співвідношення понять «оказіоналізм» та «неологізм». Як відомо, «оказіоналізм» з'являється в науковому обігу тоді, коли стає зрозуміло, що одного терміна «неологізм» недостатньо для опису розмаїття фактів, пов'язаних із появою нових слів. Однак згодом індивідуально-авторські утворення зі статусом оказіоналізмів деякі науковці намагаються вивести за межі нових слів, позбавити їх кваліфікації «неологізм», уважаючи, що «новим може бути лише те, що 3 плином часу здатне «старіти» - втрачати новизну» $[11,41]$.

Даючи негативну відповідь на запитання «Чи можна оказіональне слово назвати неологізмом?», О. Ликов керувався тим, що нові слова мають лінійний характер на часовій осі, вони з'являються в певний період і згодом перестають бути новими, потрапивши до активної або застарілої лексики; оказіональні слова не мають здатності «старіти» (у зв'язку з синхронно-діахронною дифузністю), а тому позбавлені можливості бути «новими», тим самим не можуть називатися неологізмами [11, 41-43]. Така позиція отримала чимало як прихильників, так і опонентів: перші виступали проти зарахування різних зразків оказіональних утворень до неологізмів, другі - з цим категорично не погоджуються. Так, О. Габінська висловлює цілком протилежну думку, зауважуючи, що оказіоналізм можна назвати неологізмом, бо новий - не тільки «уперше створений або зроблений, той, що недавно виник, з'явився» (антонім - старий), але й «незнайомий, маловідомий» (антонім - відомий, знайомий). «Оказіоналізми - це нові слова (неологізми), тобто слова, невідомі загальнолітературній мові, точніше більшості ії носіїв, кожне таке слово сприймають як нове, незнайоме, незвичне, незалежно від того, з якою метою воно створене: власне номінативною або експресивно-стилістичною, за якою моделлю: високо- чи малопродуктивною, непродуктивною чи один раз утіленою в слові» $[4,29]$. Логічно, зважаючи на те, що полісемічне слово «новий» має ще й семантику «який не був у вжитку», що досить яскраво підтверджує природу оказіоналізму. Оцінка того чи того факту як нового зумовлюється не тільки певною часовою протяжністю: нове - це те, що наступає за чимось іншим щодо нього в часі. Новизна в подібних випадках є не абсолютною, а відносною. Відносна ж новизна індиферентна до часу. Крім того, теорія абсолютної новизни, з позицій якої дехто намагається розглядати лексичні неологізми, досить уразлива, оскільки, по суті, «безвідносної, безумовної, не порівнюваної ні з чим» новизни немає.

Фактор часу, проте, визначали і визначають як одну з релевантних характеристик неологізму. I в зарубіжному, і у вітчизняному мовознавстві наявні спроби зняття часової відносності, натомість має місце вказівка на період виникнення: неологізми кваліфікують як «нові слова, що виникли за пам'яті людей, які їх використовують» $[9,227]$. Проте й таке витлумачення 
зумовлює значну частку суб'єктивізму в процесі зарахування цього чи того слова до розряду неологізмів певного періоду, адже об'єктивувати, датувати виникнення кожного нововведення практично неможливо. Нове явище постає як миттєвий ефект, що звичайно залишається непомітним для більшості носіїв мови і так само непомітно входить (якщо входить!) у «пам'ять людей», які починають ним послуговуватися. Через різну «лексичну компетенцію» людей одного покоління кваліфікувати ту чи іншу одиницю як неологізм виявляється так само важко.

Незважаючи на всі суперечки, які виникають у зв'язку з визначенням сутності неологізму та встановленням «набору» його диференційних ознак, більшість мовознавців переконливо доводить, що «неологізм - це, уважай, одна з небагатьох категорій, для яких фактор часу є надзвичайно релевантним» $[8,87]$, його новизна об'єктивна, встановлюється щодо будь-якого часу, вибраного довільно $[18,92]$, керуючись зокрема й тим, що «коли слово побутує вже більше двадцяти років, то навряд чи його варто вважати неологізмом» $[8,87]$, бо воно вже не «дуже нове», «новісіньке», його «новизна і свіжість» 3 плином часу не відчуваються. Виникає слушне запитання: Де та часова межа, за якою відчуття новизни втрачається та скільки потрібно часу, щоб те, що кваліфікувалося як неологізм, перестало ним бути? На жаль, відповіді на нього ніхто не дає і, очевидно, ніколи дати не зможе.

Кожен матеріальний репрезентант, закріплений у «мовному просторі», усталений у ньому, має свій початок, свою точку відліку, свій «день народження», тобто з'являється «у певний час і в певному місці», незважаючи на те, що встановити їх майже нереально. Це і є поява нового в буквальному витлумаченні цього слова. Унаслідок свідомої людської діяльності апробований мовний матеріал поєднується в нові структури, утворюючи при цьому нову якість. Те, чого раніше не було, отримує право на буття. Виникнення нового - це поява того, що ще не «відклалося», не усталилося в «мовному просторі». За такого витлумачення новими є вербальні факти, які постали в даний момент, «нині», «зараз», тобто нове зумовлюється теперішнім часом. Такий процес виникнення нового споглядати досить важко, він відбувається, так би мовити, приховано від людського ока, оскільки його результат не відразу закріплюється в «мовному просторі». Реальні свідки появи нововведення у власне комунікативному просторі відсутні, дослідження подібних явищ відбувається на основі остаточних результатів, здебільшого влаштованих у «мовному просторі».

Зважаючи на те, що новий матеріальний репрезентант - це якісний стан, а якісний стан має певну часову протяжність, можна говорити й про протяжність нового, тривалість новизни, наявність їі і в минулому («вже не тепер»), і в майбутньому («ще не тепер»). Наприклад, появу нового «ще не тепер» ілюструють деякі матеріали російськомовного словника В. Даля, що не обмежувався «інвентаризацією скарбів рідного слова», а прагнув спрогнозувати закони деривації, створити кодекс законів націо- 
нального словотворення, тобто передбачити те нове, що в майбутньому могло б з'явитися спочатку у власне комунікативному просторі, а згодом і в мовному.

Зміна якісних станів спричиняється і зміною можливостей: органічні взаємозв'язки елементів «мовного простору», модифікуючись, водночас забезпечують його протяжність і врешті-решт уможливлюють його існування як матеріальної системи.

Новизну як якісний стан не можна визначити безвідносно до чогось іншого, її встановлюють у порівнянні, у зіставленні навіть за традиційного витлумачення поняття «неологізм». Незаперечним залишається те, що новизну варто розуміти як неадаптований, унікальний, винятковий якісний стан, який характеризується неповторністю та неподібністю до вже адаптованих і для 3'ясування сутності якого повинен простежуватися відповідний каузальний зв'язок із вихідними адаптованими станами.

Цей зв'язок простежується досить чітко з огляду на те, що неадаптований якісний стан співвідноситься з поняттям «нового», а адаптований - 3 поняттям «старого». У процесі розвитку, мовного зокрема, «нове» вступає в суперечність зі «старим», про що яскраво свідчить комбінування якісних кваліфікаторів матеріальної форми вираження та змісту матеріальних репрезентантів, наприклад: а) нова форма вираження + старий зміст; б) стара форма вираження + новий зміст; в) нова форма вираження + новий зміст; г) стара форма вираження + старий зміст. У перших двох випадках боротьба «нового» зі «старим» розв'язується на користь «нового» та сприяє появі нових матеріальних репрезентантів, що уможливлює мовну еволюцію, на відміну від суперечності між старою формою вираження і старим змістом, яка стримує мовний розвиток.

Незаперечним $\epsilon$ те, що адаптуватися в «мовному просторі» й отримати певний ступінь відтворюваності в просторі власне комунікативному прагнуть не тільки новопредставлені матеріальні репрезентанти зі статусом слова, але й ті, які мають статус інших значущих мовних одиниць, зокрема номінативного характеру. Адже, як відомо, виникнення нового зумовлюється, по-перше, потребою назвати нове поняття, по-друге, бажанням замінити найменування (номінацію) цієї чи тієї реалії/ірреалії навколишнього світу новим, більш доречним для конкретної ситуації спілкування. А тому неологізм не варто ототожнювати лише з новим словом і розглядати його як один із різновидів пасивної лексики в розділі «Лексикологія»; ним можна назвати будь-яку нову номінативну одиницю, що позначає єдине поняття. Неологізми є тими новими матеріальними репрезентантами, які демонструють зміни та розвиток мови і повинні стати об’єктом вивчення неології.

Стан оказіональності для останніх - явище тимчасове, перехідне: іiі можна розглядати як один з історичних етапів існування будь-якого неологізму, як початковий етап його буття, адже все нове при своєму «наро- 
дженні» $€$ випадковим, незареєстрованим у «мовному просторі». Воно створюється не всіма носіями мови одночасно (очевидно, важко собі уявити, що будь-яке нове явище, нову номінацію продукують усім колективом в один і той же момент), а окремим індивідуумом. Доля випадкового (оказіонального) матеріального репрезентанта залежить від суспільства, узусу, що приймає/не приймає новопредставлену номему, уводить/не вводить іiі до «мовного простору» і надає/не надає можливість відтворюватися у власне комунікативних актах у типових ситуаціях.

Отже, визначення лінгвістичного статусу неологізму як одиниці лексико-семантичного рівня, яку ототожнюють переважно з новим словом, 3 позицій наукових здобутків сучасної неології є занадто вузьким, подекуди суперечливим і вимагає перегляду. Розв'язання потребують і дискусійні питання щодо співвідношення між окремими різновидами неологічного матеріалу. Конкретизація та уточнення необхідні й самому поняттю «неологізм». Ним можна означити кожну новопредставлену одиницю номінативного характеру, номему, поява якої зумовлюється потребами номінації або переномінації.

Основною диференційною ознакою неологізму є відносна новизна: нове наступає за чимось іншим щодо нього в часі, відображає не раптовий, короткочасний зріз об'єктивної вербальної дійсності, а протяжність у «мовному просторі», що є різною для різних матеріальних репрезентантів.

\section{Список використаної літератури}

1. Александрова О. И. О формировании моделей поэтического словотворчества // Актуальные вопросы лексики, словообразования, синтаксиса и стилистики современного русского языка. - Куйбышев, 1973. - С.16-32.

2. Балалыкина Э. А., Николаев Г. А. Русское словообразование: Учебное пособие. - Казань: Изд-во Казанского ун-та, 1985. - 184c.

3. Будагов Р. А. Введение в науку о языке. - М.: Просвещение, 1965. - С.88-104.

4. Габинская О. А. Типология причин словотворчества. - Воронеж: Изд-во Воронежского ун-та, 1981. $-153 \mathrm{c}$.

5. Ганич Д.І., Олійник І. С. Словник лінгвістичних термінів. - К.: Вища школа, 1985. - 360c.

6. Земская Е. А. Окказиональные и потенциальные слова в русском словообразовании // Актуальные проблемы русского словообразования: Материалы республ. научн. конф. - Самарканд, 1972. - С.19-29.

7. Земская Е. А. Словообразование // Современный русский язык / Под ред. В. А. Белошапковой. - М.: Высшая школа, 1989. - С.237-380.

8. Карпенко А. П. О неологических процесах в языке в свете дихотомии парадигматика/синтагматика // Языковые единицы в парадигматике и синтагматике: Сб. научн. тр. - Днепропетровск: Изд-во Днепропетровского ун-та, 1990. C.86-91.

9. Кочерган М. П. Вступ до мовознавства: Підручник. - К.: Академія, 2000. - 368c.

10. Кротевич С. В., Родзевич Н. С. Словник лінгвістичних термінів. - К.: АН УРСР, 1957. $-236 \mathrm{c}$. 
11. Лыков А. Г. Русское окказиональное слово: Автореф. дис.... д-ра филол. наук: 10.02.02 / Институт русского языка АН СССР. - М., 1972. - 60с.

12. Миськевич Г. И., Чельцова Л. К. Новые слова, их принятие и нормативная оценка (проблема новых слов в культурно-речевом аспекте) // Актуальные проблемы культуры речи. - М.: Наука, 1970. - С.243-276.

13. Муромцева О. Г. Розвиток лексики української літературної мови в другій половині XIX - на початку XX ст. - Харків: Вища школа, 1985. - 152c.

14. Намитокова Р. Ю. Авторские неологизмы: словообразовательный аспект. Ростов-на-Дону: Изд-во Ростовского ун-та, 1986. - 154c.

15. Сахарный Л. В. К многоаспектности словообразования как науки // Вопросы грамматики. - Пермь: Изд-во Пермского ун-та, 1972. - С.17-21.

16. Сучасна українська літературна мова: Лексика і фразеологія / За заг. ред. I. К. Білодіда. - К.: Наукова думка, 1973. - 438с.

17. Українська мова: Енциклопедія. - К.: Українська енциклопедія, 2000. - 750с.

18. Чиркова Е. К. О критериях отграничения окказиональных слов от новых слов литературного языка // Современная русская лексикография. - Л.: Наука, 1975. - C.91-102.

19. Шанский Н. М. Неологизмы // Лексикология современного русского языка: Пособие для студентов пед. ин-тов. - М.: Просвещение, 1964. - С.156-164.

\section{Summary}

The article deals with the basic methods of determining the linguistic status of neologism and its relation to the concept of «occasionalism»; the author determines a criterium of novelty as an unadapted, unique and exceptional qualitative condition characterized by its position as a work without comparison. 